I earnestly appeal, therefore, to every one who has the interests of his city and country at heart to help in thus developing the University of London, so that it may be worthy of the capital and a fruitful source of power to the empire. A public meeting has been arranged to take place in support of the scheme at the Mansion House on May 9th and the Lord Mayor has kindly consented to preside. A detailed statement of the needs of University College, London, with some account of its previous history and the part it has already played in the increase of knowledge, has been drawn up in support of the appeal and may be had on application to the secretary at the College.

Donations and subscriptions should be sent to the treasurer, Sir R. Farrant, at the College.

I have the honour to be, Sirs, your obedient servant, (Signed) REay. President.

University College, London (Gower-street, W.C.), April 11th, 1902.

\section{LARGE DOSES OF STRYCHNINE IN SURGICAL SHOCK.}

\section{To the Editors of THE LANCET.}

SIRS,-The surgeon is not content with the triumph of having chased the physician out of the abdomen; he must needs go in search of fresh laurels and this time in the domain of pharmacology. In the vew field his experiments are conducted with a boldness which surpasses his surgical daring. Hitherto strychnine has been regarded as one of those drugs which is poisonous within narrow limits, but the surgeon subscribes to no such restricted creed.

In The LanceT of April 12th (p. 1025) Mr. Mayo Robson tells us that he injects under the skin one-tenth of a grain before commencing with the anæsthesia and after the overation one-twentieth of a grain is injected every two hours if called for. In the same issue (p. 1063) Mr. C. Hamilton Whiteford is still bolder, for in an operation for pylorectomy lasting two and a half hours he injected intravenously one-fith of a grain of strychnine along with three pints of saline fluid and one ounce of brandy three-quarters of an hour before starting with the anæsthetic-certainly a fair start. During the last one and a half hours of the operation he injected into the substance of the great pectoral muscle repeated doses, the total amounting to half a grain. Now, if I mistake not the operator, this woman patient received seven-tenths of a grain or nearly three-quarters of a grain of strychnine within the space of three hours. No doubt the maximum pharmacopcial dose (one-fifteenth of a grain) may be greatly exceeded, but one may question if the quantities administered by Mr. Whiteford are within the bounds of safety. In an old number of THE LANCET there is an account from America of a patient who by mistake took one or two grains of strychnine ( 1 think the higher do-e) and recovered. The medical men kept the patient under the continuous infuence of chloroform. At the time the tale was treated as an Americanism, but after all. from what we now know of the mutual antagonism of strychnine and chloroform, the case may have been genuine. Our surgical friends tell us that the give these large doses without the "slightest twitching" (Mr. Whiteford), but this is precisely what we should look for while the patient is under the anæsthetic, because after an injection of strychnine should there be an increased activity of the reflex apparatus a few whiffs of the ether or chloroform will abolish the reflex. Even after the inhalation is stopped ether and chloroform remain for some time in the blood and will antagonise the strychnine, but they are more quickly eliminated than the strychnine, and what then? Do the surgeons never find disagreeable tonic and clonic spasms of the muscles of the extremities remaining after the effect of the anasthetic has passed off? Do they never see frequentlyrecurring or long-protracted spasms involving the respiratory muscles and threatening life itself-or worse? I think that before accepting the teaching of the new pharmacology we are entitled to enlightenment on these points. I am, Sirs, yours faithfully,

Leeds, April 14th, 1902. GORDON SHARP.

PAYING WARDS OR PAYING HOSPITALS. To the Editors of THE LANCET.

SIRS, - I welcome the article on this subject which appears on page 1124 of THE LANCET for April 19th. The writer, however, appears to be under some misapprehension, as the idea of a paying hospital is not new and the proposal was thoroughily thre:shed out and received the support of the medical profession and THE LANCET 25 years ago, as will be seen by reference to the leading articles on the subject published in THE LANCET of April 28th, May 12th, and June 23rd, 1877, where the whole matter is dealt with exhaustively and in detail. Many things have happened during the quarter of a century which has elapsed and for the greater part of that period a home or paying hospital which was established as a result of the discussion in 1877 has been conducted at a profit at Fitzroy House, Fitzroy-square. As the person who was most identified with the original proposal for the establishment of a pay hospital proper, I of course recognise that it is a good thing in itself and has much to recommend it on its merits, as I proved in my book "Pay Hospitals of the World," published in 1879. Experience demonstrates, however, that the pay hospital, whilst it will meet the needs of many persons who are prepared to pay for hospital treatment at a remunerative rate, cannot effectually prevent hospital abuse nor restrict the advantages offered by free hospitals to those members of the community who are alone entitled to receive these benefits.

For these reasons and others the paying hospital has little or nothing to do with the proposal to establish pay wings containing nothing but paying wards in connexion with the general hospitals in this conntry. This latter development is called for because there is no other means whereby the everincreasing growth in the number of hospital patients can be effectually regulated and hospital abuse prevented. We must have a reform in our present methods of hospital relief or there is a very real danger that the rising generation will demand free hospital treatment as a birthright no matter what their means may be, and so great injury must ensue to the moral fibre of the nation as a whole. Free medical relief has a tendency, unless given with a due regard to the social position of the recipient, to make against habits of thrift and self dependence.

I see good cause to believe that the London hospitals are within a measureable distance of the day when the revenue available for their support will be ample to meet the expenditure, providing the relief they give is strictly confined to those classes alone who are entitled to receive it. Twenty. five years ago it was held by THE LANCET, by the profession, and by many hospital managers "that the necessary accommodation for paying patients might be in part provided by existing hospitals, so far as London is concerned and that all that would be needed would be to adopt a certain portion of the space for paying patients and to decide upon a scale of charges, sufficient to pay the expenses of maintenance." Since then the ever increasing pressure upon hospital beds and the necessity for securing in any system of paying wards that the just rights and privileges of the whole of the medical profession should be conserved, have convinced those who have studied the question most closely, that the paying wards must be in a separable building, with an entrance quite distinct and apart from the free hospital and its administration department. Then, under fixed conditions, it will be possible to secure that (1) all abuse in connexion with the in-patient departments of the free hospitals shall cease; (2) adequate accommodation for every class of person who desires hospital treatment for payment in whole or in part; (3) the medical service shall be paid for and organised upon a plan which shall protect the interests of every member of the profession, including the members of the hospital staff as well as the general practitioners ; (4) the wisest economy in administration shall be secured; $(5)$ the training of nurses for private work shall at length be made efficient; and (6) a check will be effectually placed upon the improper growth of medical treatment in hospitals by preventing those who can afford to pay from obtaining such relief without payment, as they do at present.

It follows, in my judgment, that whereas the pay hospital, as the experience of Fitzroy House shows, can be established and made a success financially there is a danger that pay hospitals upon commercial lines might result in injury rather than benefit to the great body of medical practitioners. This danger would be obviated by the institution of the paying ward in connexion with the large general hospitals of this country upon the plan I have indicated, because in this way, and in no other way that I have been able to discover, can adequate guarantees be secured that the present large 
and increasing abuse of the free hospitals in Great Britain shall be rendered impossible and that the just rights of the profession should be conserved.

I am glad that THE LANCET has dealt with the matter so ably in its leading columns. I hope that the questions raised may be fully discussed in THE LANCET and that the managers of any general hospital who would be prepared to provide a site on which a pay wing could be erected and to accept such pay wing as a free gift, subject to the undertaking that they will administer and maintain it on conditions to be mutually agreed, will communicate with me on the subject. In no better way can the general feeling of hospital managers be accurately ascertained or the necessary steps be attempted whereby pay wings may be secured without trespassing upon the finances of the hospitals or the energies of hospital managers, the whole of which are required to enable them to provide the means to defray the cost of the free departments of our general hospitals.

$$
\text { I am, Sirs, yours obediently, }
$$

HENRY C. BuRdetT.

The Lodge, Porchester-square, W., April 19th, 1902.

\section{OPERATIONS FOR THE EXTRACTION OF CATARACT.}

To the Editors of THE LANCET.

SIRs,-The large percentage of cases in which prolapse of the iris occurred after extraction of cataract in the series of operations reported by Captain R. H. Elliot, I.M.S., in THE LANCET of April 12th, p. 1031, must lead to the supposition that some other factors may have contributed to such a high percentage-viz., 21-14-a result much in excess of the figures of Knapp as well as contrary to the usual experience. Apart from the unruly conduct of the patients after operation it seems probable that atropine had been freely used beforehand in order to produce sufficient mydriasis to allow of the preliminary step described of capsule rupture with Bowman's needle, and that thereby the normal tension of the eyeballs in these senile or prematurely old patients had been raised to such an extent as, coupled with the associated paralysis of the sphincter iridis, directly to conduce to this accident. would be interesting to learn if my surmise be correct.

I am, Sirs, yours faithfully,

W. A. LEE.

Junior Constitutional Club, Piccadilly, W., April 12th, 1902.

\section{THE DISSEMINATION OF SMALL-POX AND THE HOLIDAYS OF LONDON CHILDREN. \\ To the Editors of THE LANCET.}

Sirs, - The 50,000 London children who look to spend their holidays in country cottages are threatened with disappointment on account of the fear of small-pox. If they are left for all August in the streets about their homes there will be a loss both in national strength and in childhood's joy. Medical officers are, of course, right in wishing to protect their own areas from disease : but I would, with your permission, submit some reasons why they should not altogether exclude London children. 1. The isolation of London is impossible. There is daily contact between people coming and going to the country. The tramps alone constitute a perpetual danger. The only security of an area from small-pox is in the vaccination of its own inhabitants; this is so effective that the disease is less dangerous than fever. 2. The small-pox is affecting only a very small proportion of the population. There are fewer small-pox patients than there are fever patients. The committees sending the children would be responsible that all sent are vaccinated and that none go from districts known to be infected. 3. I would therefore ask country medical officers not to set their faces against our plan of sending children to country cottages-I would even go further and ask them, on national grounds, to forward the plan and induce landlords and cottagers to welcome the children. The strength of the nation lies more and more in the town. If town life is not made bealthy our people cannot be strong either to iabour or to fight. Town and country are parts of one whole. Country people making town children welcome in country families and interesting them in country pursuits and giving them the strength of country air and change would take away some of the hardships of town life.

1 am, Sir-, yours faithfully,

Toynbee Hall, Whitechapel, E., A pril 22ncl, 1902.

$$
\text { SAMUEL R. BARNETT. }
$$

\section{CARDIAC INADEQUACY.}

\section{To the Editors of THE LANCET.}

Sirs, - Will you allow me a word by way of comment on Dr. Alexander Morison's interenting paper on Cardiac Inadequacy, published in THE LANCET of April 19th, p. 1098? That individuals are variously endowed in respect of cardiac adequacy, and that some come into the world with less than their proper share of cardiac muscle, few will doubt. It is evident that those thus slenderly endowed are placed at a disadvantage when stress is put upon the cardio-vascular system, and that under such stress the circulation will fail more readily in their case than in that of their more highly endowed brethren. So far I am at one with Dr. Morinon, but I venture to think that the two cases which he brings forward in support of this thesis are valueless for the purpose.

From the facts as related by him one can have little hesitation in affirming that in each of the cases the small heart bore up bravely and well to the end, and was irresponsible alike for the dropsy that was present-in the first case at least it is evident that Dr. Morison regarded the dropsy as of cardiac origin-and for the premature death that occurred. Dr. Morison expressly tells us that the cardiac walls were hypertrophied and that the chambers were relatively small; this conclusively proves that systole was adequate and that there was no back pressure; had systole been inadequate for a protracted period dilatation of the inadequate chamber must inevitably have resulted.

I am, Sirs, yours faithfully,

Wimpole-street, W., April 20th, 1902. HARRY CAMPBELI.

\section{OÖPHORECTOMY FOR CANCER.}

\section{To the Editors of THE LANCET.}

Surs, - In your issue of April 19th I see that Dr. A. ' $\mathrm{T}$. Davies, in referring to the operation of oöphorectomy for mammary cancer, says that I consider it "horrible" (p. 1090). Will you allow me to point out that this is incorrect. What I really did say was, that the operation is a "horrible mistake": (1) because removal of the uvaries tends to favour rather than to prevent the development of cancer, in support of which I instanced the great frequency of cancer after ovariotomy for non-malignant ovarian cysts, \&c. ; (2) because of its proved curative inefficaciousness, for although hundreds of these operations have been done, not a single cure can be instanced; and ( 3 ) because there never has been any scientific basis for such a procedure. The essential thing I wished to call attention to was the mistake that had been made in resorting to this operation in these circumstances, and the qualifying adjective used is a matter of no importance.

I am, Sirs, yours faithfully,

Clifton, Bristol, April 19th, 1902. $\quad$ W. Roger WrLtuams.

\section{THE OBSTETRICIAN-PHYSICIAN OR SURGEON?}

\section{To the Editors of THE LANCET.}

SIRS, - Under the above heading is published in THE LANCET of April 19th, p. 1138, a letter from Dr. Stitt Thomson, junior physician to the Lincoln County Hospital. The same letter appeared in the Lincolnshire Fcho of April 9th, on the eve of the meeting of the hospital board. In it he states: "but that I was remonstrated with by the senior surgeon is untrue." On March 24th, two days after returning from abroad, I wrote to Dr. Stitt Thomson and in my letter I said: "I may remind you that when $I$ objected to your doing certain minor operations some months back you assured me that you wished to do nothing which was against the custom of the hospital and the wishes of the staff." This statement of mine remained uncontradicted until the publication of the Lincolnshire Echo above mentioned. I can only repeat that I did remonstrate with Dr. Stitt Thomson and express regret that not only has he apparently forgotten that fact but has 